\title{
Teacher pay and teacher aptitude ${ }^{\text {is }}$
}

\author{
Andrew Leigh* \\ Research School of Economics, Arndt Building, Australian National University, ACT 0200, Australia
}

\section{A R T I C L E I N F O}

\section{Article history:}

Received 31 July 2010

Received in revised form

10 November 2011

Accepted 2 February 2012

\section{JEL classification:}

H52

I22

J45

Keywords:

Salary

Occupational choice

Teaching

\begin{abstract}
A B S T R A C T
Can changes in teacher pay encourage more able individuals to enter the teaching profession? So far, studies of the impact of pay on the aptitude distribution of teachers have provided mixed evidence on the extent to which altering teacher salaries represents a feasible solution to the teacher quality problem. One possible reason is that these studies have been unable to separate labor supply effects from labor demand effects. To address this, I model the relationship between current salaries and the academic aptitude of future teachers (those entering teacher education courses). Using a unique dataset of test scores for every individual admitted into an Australian university between 1989 and 2003, I explore how interstate variation in average pay or pay dispersion affects the decision to enter teacher education courses. A 1 percent rise in the salary of a starting teacher boosts the average aptitude of students entering teacher education courses by 0.6 percentile ranks, with the effect being strongest for those at the median. This result is robust to instrumenting for teacher pay using uniform salary schedules for public schools. I also find some evidence that more pay dispersion in the non-teaching sector lowers the aptitude of potential teachers. (c) 2012 Elsevier Ltd. All rights reserved.
\end{abstract}

\section{Introduction}

Recent studies have provided substantial evidence in favor of two propositions: teacher quality is an important

\footnotetext{
is I am grateful to Associate Editor Ron Zimmer, two anonymous referees, Brian Jacob, Phil Lewis, Derek Neal, Andrew Norton, Jonah Rockoff, and seminar participants at the Australian Labour Market Research workshop, the Australian National University, an IFN conference on 'Beyond the Resource Constraint: Alternative Ways to Improve Schooling', the IZA/SOLE Transatlantic Meeting of Labor Economists, the NBER Economics of Education program meetings and the University of Sydney for helpful comments and suggestions, to Aleks Alimpijevic, Fiona Sutherland and Phil Trickett for assistance in obtaining tertiary entrance data, and to Andrew Bull, Andrew Cappie-Wood, Linda Gale, Joanne Galpin, Greg Martini, Graeme Payne, Jackie Peterson, Don Wilson and Carol Zanetti for assistance in collating uniform teacher pay scales for the various states and territories. Susanne Schmidt and Elena Varganova provided outstanding research assistance. This research was supported under the Australian Research Council's Discovery funding scheme (project number DP0665260).

* Tel.: +61 116126125 1374; fax: +611161261250182.

E-mail address: andrew_leigh@ksg02.harvard.edu
}

determinant of student achievement; and teacher aptitude has declined substantially over the past generation. Partly as a result of this research, raising the average quality of the teaching workforce has received increasing policy attention.

One way that teacher quality might be improved is by altering the pay structure within the teaching profession. Yet existing studies do not provide a clear picture of the relationship between teacher salaries and teacher quality. One problem is that of determining causation. Do salaries affect teacher quality, or does teacher quality affect salaries? For example, suppose that exogenous salary increases attract better teachers, but that when education authorities observe more applicants for teaching jobs, they lower salaries (to cut costs). In this scenario, the supplyside and demand-side effects will offset one another, and an outside observer might erroneously conclude that higher salaries do not attract better teachers.

To address this problem, this study uses a different approach to the existing literature. Instead of looking at the quality of current teachers, I instead focus on the group from which future teachers will be drawn: those studying 
teacher education. Because the typical teacher education student will not enter the teaching profession for another four years, it is unlikely that educational authorities will take account of the quality of teacher education students when setting salaries. Any observed relationship between teacher pay and teacher aptitude is therefore likely to be driven only by supply-side effects. ${ }^{1}$

The identification strategy in this paper uses variation in teacher pay and teacher aptitude within states over time in Australia. For public school teachers, teacher salaries are set by statewide collective bargaining, and students are required to choose their major (e.g. teacher education) at the time of entering university. Like the US, Australia appears to have experienced a significant decline in the academic aptitude of new teachers over recent decades.

To measure the academic aptitude of teacher education students, the research utilizes a unique dataset, containing test scores for every student entering university over a 15 -year period. In effect, this makes it possible to compare the scores of students entering teacher education courses with the scores of students entering other courses. Matching this to detailed information on the salaries of new teachers makes it possible to estimate the impact of changes in teacher pay on the quality of potential teachers.

Controlling for state-specific and time-specific effects, I find that raising average pay has a positive and significant impact on the aptitude of those entering teacher education courses. This result is robust to instrumenting for average teacher pay with the uniform salary schedules for public schools. Furthermore, there is evidence that earnings inequality in the non-teaching sector lowers the aptitude of potential teachers. Looking across the distribution of teacher test scores, the impact of an increase in average pay is strongest at the middle of the teacher aptitude distribution, while pay dispersion mostly affects those further up the distribution.

The remainder of this paper is organized as follows. Section 2 briefly discusses the relevant literature. Section 3 outlines a simple model of teacher aptitude. Section 4 presents the empirical strategy and results. Section 5 presents several robustness checks, and the final section concludes.

\section{What do we know about the nexus between teacher quality and teacher pay?}

Studies of US teacher quality have shown that the performance gap between the best and worst teachers is substantial. Using panel data, with teacher and student fixed effects, Rockoff (2004) and Rivkin, Hanushek, and Kain (2005) conclude that moving up one standard deviation on the teacher quality distribution leads to a

\footnotetext{
1 In theory, it is possible that employers and unions take account of the test score distribution of new teacher education students when negotiating salary agreements. However, I am not aware of any evidence (empirical or anecdotal) suggesting that this has ever occurred. Given that many union agreements operate on a three-year cycle, this would effectively involve the parties setting a salary agreement with an eye to workers who would not enter the labour market at any point in the life of that pay deal.
}

gain in student achievement of approximately 0.1 standard deviations. This suggests that switching from a teacher at the 10th percentile to a teacher at the 90th percentile would raise a student from the median to the 60th percentile.

At the same time, researchers using a variety of different surveys have shown that the academic aptitude of those who enter teaching in the US has fallen over the past 3-4 decades. Corcoran, Evans, and Schwab (2004) combine five longitudinal surveys and find that the percentage of teachers who were placed in the top twenty percent on national achievement tests fell markedly from the early 1970 s to 2000. Evidence from the National Longitudinal Surveys of Youth (Bacolod, 2007) and the ACT exam (Leigh \& Mead, 2005) support this conclusion. In Australia, Leigh and Ryan (2008) looked at changes in the literacy and numeracy standards of teacher education students and new teachers. Between 1983 and 2003, they found that the average percentile rank of those entering teacher education fell from 74 to 61 , while the average percentile rank of new teachers fell from 70 to 62 .

Do teachers with higher academic scores add more value in the classroom? Most - though not all - of the studies that have looked at the relationship between teacher test scores and student achievement have found a positive association. This relationship appears to hold for teachers' scores in state teacher certification exams (Clotfelter, Ladd, \& Vigdor, 2006; Ferguson \& Ladd, 1996; Ferguson, 1991; Goldhaber, 2007), for teachers' exams when they were in high school (Ehrenberg \& Brewer, 1994), and for cognitive tests administered to new teachers (Rockoff, Jacob, Kane, \& Staiger, 2008). Comparing various predictors of teacher quality, Ehrenberg and Brewer (1994) concluded that a teacher's own test scores and the selectivity of the college that the teacher attended are both positively related to pupil achievement, with the teacher's test scores having the stronger effect. ${ }^{2}$ I am not aware of any Australian papers that have estimated the relationship between teachers' test scores and student achievement.

Several studies have sought to determine the impact of teacher pay on teacher quality. Given that we observe a positive relationship between test scores and wages across the labor market (Murnane, Willett, \& Levy, 1995 for the US; Marks \& Fleming, 1998 for Australia), it would perhaps be surprising if the same did not hold true in the labor market for teachers. However, Ballou and Podgursky $(1995,1997)$ presented simulations showing that since teaching labor markets are typically in a state of excess supply, raising average teacher pay would have a small effect at best on the SAT scores of prospective teachers. Exploiting natural variation in average salaries across school districts at a single point in time, Figlio (1997) found that districts with higher teacher salaries tend to attract more teachers from selective colleges and with subject matter qualifications.

\footnotetext{
2 A meta-analysis by Hanushek (1997) found that in $64 \%$ of studies looking at the relationship between teacher test scores and student outcomes, the relationship was positive, while the relationship was negative in only $25 \%$ of studies (in the remaining $11 \%$ of studies, the sign was unspecified). Note however that not all of the $64 \%$ of studies found a statistically significant relationship between teacher test scores and student achievement.
} 
While Figlio controlled for several observable factors that may affect both teacher pay and teacher quality, the use of a single cross-section raises the possibility that certain districts have unobservable characteristics that are correlated with both teacher pay and teacher quality (for a discussion of the role of compensating differentials in this context, see Clotfelter, Glennie, Ladd, \& Vigdor, 2008; Hanushek, Kain, \& Rivkin, 1999). ${ }^{3}$

Other researchers have estimated the direct impact of teacher pay on student outcomes. A standard approach is to construct repeated cross-sections from US states in census years, allowing estimation of models with state and year fixed effects. Card and Krueger (1992) used variation in teaching wages across states, and found that a $10 \%$ rise in teachers' salaries led to a 0.1 percentage point increase in the rate of return to schooling for white males born between 1920 and 1949. Loeb and Page (2000) also used state-level variation in relative teachers' wages from the 1960 to 90 censuses, and found that a $10 \%$ increase in the teaching wage reduced the high school dropout rate a decade later by $3-4 \%$. And across OECD countries, Boarini and Lüdemann (2009) and Dolton and MarcenaroGutierrez (2011) find that higher teacher salaries are associated with higher test scores.

However, other studies have found a weak or nonexistent relationship between pay and student performance (see Betts, 1995 using the National Longitudinal Survey of Youth; Grogger, 1996 using the High School and Beyond survey). In a meta-analysis of 118 studies, Hanushek (2006) tallied up 20 studies finding a significant positive relationship between teacher pay and student performance and 7 finding a negative relationship, with the remainder finding a statistically insignificant relationship. ${ }^{4}$ So far as I have been able to ascertain, there is no empirical evidence on the relationship between teacher quality and student performance in Australia.

\section{A simple model of teacher aptitude}

In the Australian context (as in most European countries, though not in the US), students must choose their college major at the time of entry into university. Although moving between courses is theoretically possible, in practice most students remain in their chosen major until graduation. College entry is determined almost entirely by statewide examinations, with each course in each college

\footnotetext{
${ }^{3}$ Other indirect evidence comes from Figlio and Rueben (2001), who found that states which imposed local tax limits (whose effect was often to reduce teacher pay) also saw a fall in the academic aptitude of new teachers.

${ }^{4}$ See also Hanushek (1997). A related set of studies analyze the relationship between teacher pay and the supply of teachers, finding a positive relationship (Chung, Dolton, \& Tremayne, 2004; Zabalza, 1979). Another literature looks at the decision to quit teaching, and generally finds a robust relationship between pay and retention (cf. Dolton \& van der Klaauw, 1999; Frijters, Shields, \& Wheatley-Price, 2004; Hanushek et al., 1999). In the Australian context, Webster, Wooden and Marks (2004) cite a survey by the Ministerial Council on Education, Employment, Training and Youth Affairs, which found that the most frequently mentioned factor that would assist retention was remuneration, rating above reduced workloads and improved employment conditions.
}

having its own entry cutoff. The number of places in each course and college is predetermined by the college and the federal government. For the typical young Australian, the occupational choice is therefore made at the end of high school.

Moreover, the course choices of high-ability students will affect the choices available to low-ability students: if a large number of high-ability students switch to a particular course, the minimum entry standard for that course will rise, preventing low-ability students from enrolling. The test score distribution in teacher education courses therefore reflects the number of available places in these courses, and the demand by students. Since the vast majority of students attend a university in their state, I assume that students do not move across state boundaries to attend university, and that they do not move to a different state to teach after graduating (the former assumption is less important than the latter). ${ }^{5}$

To model this environment, I suppose a simple career choice model in which all individuals select a teaching or alternative non-teaching career at the end of their high schooling. ${ }^{6}$ This is akin to the occupational choice model that has been previously used to consider the decision to enter engineering (Freeman, 1976; Ryoo \& Rosen, 2004), law (Rosen, 1992) and teaching (Flyer \& Rosen, 1997). ${ }^{7}$

For simplicity, suppose that the alternate occupation also requires a college degree, requiring the same number of years of postsecondary studies as a teaching qualification (this makes it possible to ignore the costs of university education). Assume also that in making the occupational choice, students' decisions are not influenced by the possibility of switching into a different career later on. ${ }^{8}$

\footnotetext{
5 In 2003, only 9.8\% of commencing Australian university students were studying at a university in a different state from their state of residence. Source: author's calculations, based on Department of Employment, Science and Training (DEST), Selected Higher Education Statistics, Section 3.1, Table 4 (2003). In earlier years, this figure was almost certainly lower, since exams were not standardized across all states until the mid-1990s. Teaching in a different state after graduation is not impossible, but is made less likely by the fact that teacher education students build up contacts with local schools through their practicum teaching. Almost all Australian universities are in the major cities; very few are near state borders.

${ }^{6}$ If wages are flexible, an exogenous wage rise will lead to an influx of new entrants, which will in turn depress the equilibrium wage. Rational expectations models assume that agents take into account this feedback effect, while static expectations ("cobweb") models assume that agents ignore feedback effects, and therefore that entrants overreact to current shocks. My model is consistent with either rational or static expectations, and with only a short panel, I do not attempt to distinguish between them. In practice, Australian teaching wages are likely to be considerably more rigid than (for example) US engineering wages, which will reduce the feedback effect.

${ }^{7}$ The results of Flyer and Rosen (1997) are not directly comparable with mine. Their focus is on the gender composition of teaching, and the fact that - in contrast with other occupations - female teachers who take temporary leaves are not penalized in future earnings growth.

${ }^{8}$ Leigh and Ryan (2006, Appendix I) tabulate data from the Longitudinal Surveys of Australian Youth, covering individuals who graduated from high school in the 1980s and 1990s. Among those who are observed studying teacher education in either of the first two years after they could possibly have been in Year 12, 75\% were working as teachers in the fourth, fifth or sixth years after they could possibly have been in Year 12; implying an attrition rate of around one in four. To the extent that students consider the possibility of switching careers, my results may mis-estimate
} 
The probability that individual $i$, living in state $s$, in year $t$ chooses a teaching career (denoted by the superscript $\mathrm{TCH}$ ), instead of an alternative non-teaching career (denoted by the superscript ALT) will therefore be determined by four factors: the individual's expected pay in teaching, the expected pay in an alternative occupation, the expected non-wage characteristics of teaching, and the expected non-wage characteristics of the alternative occupation.

$$
P(\text { Teach })_{i s t}=F\left[E\left(W_{i s t}^{T C H}\right), E\left(W_{i s t}^{A L T}\right), E\left(N W_{i s t}^{T C H}\right), E\left(N W_{i s t}^{A L T}\right)\right]
$$

Based on the above assumptions, teacher quality will therefore be affected by the average wage in teaching and alternative occupations, the non-wage characteristics in teaching and alternative occupations, and the quantity constraint imposed by the government on the number of places in teacher education courses and courses leading to alternative occupations. $^{9}$

Suppose further that the non-wage characteristics (compensating differentials) in teaching and alternative occupations do not vary by ability, but that wages do vary by ability, with WHigh denoting the average wage of a highability person, and WLow the average wage of a low-ability worker. ${ }^{10}$ The mean quality of those entering teacher education courses in a given state and year $(\overline{T Q})$ will therefore be determined by:

$$
\begin{aligned}
\overline{T Q}_{s t}^{T C H}= & F\left(\bar{W}_{s t}^{T C H}, \bar{W}_{s t}^{A L T}, \frac{W H i g h_{s t}^{T C H}}{W L o w_{s t}^{T C H}}, \frac{W H i g h_{s t}^{A L T}}{W L o w_{s t}^{A L T}},\right. \\
& \left.\overline{N W}_{s t}^{T C H}, \overline{N W}_{s t}^{A L T}, Q_{s t}^{T C H}, Q_{s t}^{A L T}\right)
\end{aligned}
$$

The first two terms in parentheses are the average teaching wage and the average wage in alternative occupations. The third and fourth terms capture pay variance within teaching and in alternative occupations (as measured by the ratio of high-ability to low-ability wages).

the medium-run and long-run effects of teacher salary on teacher aptitude. A referee also points out that a high proportion of those who switch out of teaching move into educational administration. It is therefore possible that the salary schedules in educational administration are salient for some people considering a career in teaching. If educational administrators tend to be of higher (lower) aptitude than teachers, this effect would be stronger at the top (bottom) of the teacher aptitude distribution.

${ }^{9}$ One piece of evidence suggesting that potential teacher education students are aware of teacher salaries can be found on the website of the education faculty at the University of Sydney (sydney.edu.au/education social_work/future_students/careers/teacher_salaries.shtml, checked 11 Nov 2011). Potential applicants are told: 'In Australia, teacher salaries are generally above the average weekly earnings and a beginning teacher's salary is above the average salary for new graduates. New South Wales teachers are currently among the best paid teachers in Australia.' The website then goes on to list the prevailing salary scales.

10 In practice, the assumption that compensating differentials do not vary by ability is unlikely to hold in all instances. However, this is unlikely to create a substantial bias. Student-teacher ratios, the proxy I use for non-wage benefits in teaching, are typically set at a state level, not a school level. In alternative occupations, it is more plausible that compensating differentials might be positively correlated with ability, but to the extent that compensating differentials are proportional to salaries, the pay variance terms will capture these effects.
The fifth and sixth terms are the non-wage benefits in teaching and alternative occupations, and the last two terms are the number of places available in teaching courses and non-teaching courses (a government-imposed quantity constraint).

Within this simple model, we should expect the partial derivative of teacher quality with respect to the teaching wage to be positive, and the partial derivative with respect to the non-teaching wage to be negative. Likewise, as in Roy (1951) and Hoxby and Leigh (2004), if the returns to ability are positively correlated across occupations, then the partial derivative of teacher quality with respect to teaching pay variance should be positive, while the partial derivative of teacher quality with respect to pay variance in alternative occupations should be negative. We should expect the partial derivative of average non-wage benefits in teaching and non-teaching occupations to have the same sign as the respective average salary terms. The partial derivative of teacher quality with respect to the availability of teacher training positions is expected to be negative, since expanding the number of available places in teacher education courses will have the effect of lowering the entry cutoff for these courses. Conversely, the partial derivative on the number of places in other courses is expected to be positive.

\section{Empirical strategy and results}

To test the theoretical model, I use as a proxy for teacher quality the test score rank of those who enter teacher education courses. As noted above, this is an imperfect measure of teacher quality, though most studies find that students perform better when taught by teachers with higher academic aptitude. I estimate an equation in which $\overline{T E R}$ denotes the average tertiary entrance rank of those entering teaching in a given state and year, and $\bar{W}$ is the average wage. Since I do not observe the returns to ability in a given occupation, I proxy it with the variance in starting salaries. Specifically, I estimate the interquartile ratio of earnings (W75/W25) in teaching, and in alternative occupations. ${ }^{11}$ Within teaching, salary variance arises from pay dispersion within the government school sector (which is likely to be minimal), pay dispersion within the non-government school sector, and pay gaps between the government and non-government school sectors. In non-teaching occupations, salary variation reflects both inter-occupational and intra-occupational pay dispersion.

As a proxy for the non-wage benefits in teaching, I include $\overline{\text { ClassSize, }}$ the student-teacher ratio in a given state and year. ${ }^{12}$ Places denotes the number of university places in teaching and alternative courses made available by the federal government in a given state and year (each expressed as a share of those graduating from year

\footnotetext{
11 The results are quite similar if estimated using the $90 / 10$ ratio or the Gini coefficient to measure pay dispersion.

12 The within-state standard deviation of class size ranges from 0.3 to 0.6 . Note that in the estimating equation, I do not include a proxy for nonwage benefits in the non-teaching sector. Such a measure would have to be something that affected most workers in the non-teaching sector, but did not affect teachers.
} 
12 in that state in the previous year). ${ }^{13}$ To control for general labor market effects, Unemp is the state unemployment rate, and $\delta$ and $\gamma$ are state and year fixed effects respectively. ${ }^{14}$ The state fixed effects absorb time-invariant unobservables in a state that are correlated with both teacher pay and the aptitude of potential teachers. Year fixed effects absorb factors that affect all states at the same time, such as labor market shocks, or demographic cycles affecting student enrolment and teacher retirement. Standard errors are clustered at the state level, to take account of serial correlation (Bertrand, Duflo, \& Mullainathan, 2004). Where $g$ indexes gender, $s$ indexes states, and $t$ indexes years, the equation to be estimated is:

$$
\begin{aligned}
\overline{T E R}_{g s t}^{T C H}= & \alpha+\beta_{1} \ln \left(\bar{W}_{s t}^{T C H}\right)+\beta_{2} \ln \left(\bar{W}_{s t}^{A L T}\right)+\beta_{3} \frac{W 75_{s t}^{T C H}}{W 25_{s t}^{T C H}} \\
& +\beta_{4} \frac{W 75_{s t}^{A L T}}{W 25_{s t}^{A L T}}+\beta_{5}{\overline{\text { ClassSize }_{s t}}}^{\text {TCH }}+\beta_{6} \text { Places }_{s t}^{T C H} \\
& +\beta_{7} \text { Places }_{s t}^{A L T}+\beta_{8} \text { Unemp }_{s t}+\beta_{9} \text { Female }_{g} \\
& +\delta_{s}+\gamma_{t}+\varepsilon_{g s t}
\end{aligned}
$$

Tertiary entrance rankings are available for all students who commenced an undergraduate degree or diploma course at a university between the years 1989 and 2003. These figures are provided annually by universities to the Department of Education, Employment and Workplace Relations (known as the Department of Employment, Science and Training during the period analyzed here). Although test scores are comparable across universities in the years 1999-2003, universities did not report on a common metric in earlier years. I therefore convert all scores into within-state percentile rankings. Over the years 1999-2003, the correlation between this derived ranking and the comparable tertiary entrance rank(the Universities Admissions Index) is 0.94

I calculate salary information using microdata from the annual Graduate Destination Survey (GDS). For both teachers and non-teachers, salaries are for those employed full-time. This leaves around 35,000 respondents per year, of whom about 15 percent are teachers. The large

\footnotetext{
13 Since there are only two private universities in Australia, almost all those studying teacher education attended a public university, where the number of places is set by the federal government. For example, in 2003, $98 \%$ of university students majoring in education attended a public university. Source: author's calculations, based on DEST (2003, Section 3.2, Table 18). Although it is theoretically possible for universities to fail to fill their assigned places, this appears to be rare in practice. The Australian government does not systematically publish figures on this issue, but did release data pertaining to 2006, which showed that 0.3 percent of places in that year were handed back (DEST, 2007, Section 3.1, Table 1; Healy, 2008). Healy (2008) attributed the handbacks in 2006 to the booming Australian economy, implying that a lower share of places would have been handed back in the period 1989-2003.

14 In Australia, the school year runs from February to December. Students in year 12 typically rank their university preferences in November of their graduating year, and have a brief opportunity to revise them when they learn their tertiary entrance rank the following January. Therefore, where the tertiary entrance rank relates to those entering university in year $t$, the main variables on the right side of the equation (salary figures, unemployment rates, and student-teacher ratios) are averaged across years $t$ and $t-1$.
}

sample size of the GDS allows me to calculate four salary measures for each state and year: average salary for teachers, average salary for graduates in non-teaching occupations, the interquartile ratio of earnings in teaching, and the interquartile ratio of earnings in non-teaching occupations. ${ }^{15}$

To ensure that the non-teachers are sufficiently comparable to teachers in the sample, I exclude those who have graduated with a postgraduate qualification (e.g. Masters or $\mathrm{PhD}$ ), and drop from the sample respondents who are not working or are working part-time. Although the GDS does not contain information on weeks worked per year, average hours worked per week are very similar across teachers and non-teachers. Other institutional features do not suggest that teachers face significantly harder or easier working conditions than other university graduates in their first job. For example, over the period in question, Australian states did not require new teachers to sit an exam before they were permitted to teach. More information about the key variables is supplied in the Data Appendix.

Table 1 presents summary statistics at the level of stateyear-sex cells. The number of cells is 213 , which is slightly below the potential maximum of 240 , due to 4 missing wage observations and 23 missing tertiary entrance score observations (see Data Appendix for details). Since these missing observations affect the three smallest jurisdictions (the Australian Capital Territory, the Northern Territory, and Tasmania), they are unlikely to have an impact on the (weighted) regression results.

Fig. 1 shows a kernel density plot of the percentile ranks of the entrants into teacher education courses in the period 1989-2003, based on the 89,970 teacher education students for whom TER scores are available. The distribution has a hump below 40 , and steadily declines thereafter. The interquartile range is from 17 to 51 , while the median is 33. Note that although those in teacher education courses rank below average for university entrants, they still rank above average if compared with their entire age cohort. ${ }^{16}$

Table 2 shows the results from estimating equation (3), first for all entrants into teacher education courses, and then separately by gender. Average teacher pay appears to have a positive and significant impact on the aptitude of those entering teacher education courses. In the pooled

\footnotetext{
15 Ideally, one would like to have a measure of the net present value of expected lifetime earnings rather than simply the starting salary. However, starting salaries will be a reasonable proxy if the individual has a high discount rate, or if there is a strong degree of correlation between starting earnings and lifetime earnings in teaching and in non-teaching occupations. In the case of public school teachers, this second assumption does indeed hold: when the uniform salary schedule is increased, the percentage change is almost always the same at all points on the salary scale. Consequently, when a university entrant observes a $5 \%$ increase in the salary of starting teachers in public schools, this effectively represents a 5\% increase in expected long-run earnings if he or she works as a public school teacher in that state.

16 Over the period 1999-2003, test scores for all university entrants are scaled according to the Universities Admissions Index (UAI), which is designed to rank individuals against all those in their age cohort, taking into account the fact that about one-quarter of students drop out of school before year 12 . In this period, the mean UAI for entrants into teacher education courses was 77, the interquartile range was 70-85, and the median was 78.
} 
Table 1

Summary statistics.

\begin{tabular}{|c|c|c|c|c|}
\hline Variable & Mean & SD & Min & Max \\
\hline Percentile ranking & 34.484 & 5.964 & 10.500 & 51.342 \\
\hline Log teacher salary & 10.373 & 0.134 & 10.094 & 10.671 \\
\hline Log salary in alternative occupations & 10.362 & 0.138 & 10.072 & 10.712 \\
\hline Interquartile ratio (IQR) in teaching & 1.024 & 0.010 & 1.003 & 1.040 \\
\hline Interquartile ratio (IQR) in alternative occupations & 1.038 & 0.003 & 1.029 & 1.052 \\
\hline Student-teacher ratio & 15.194 & 0.720 & 13.100 & 16.400 \\
\hline Teacher education places per high school graduate & 0.102 & 0.029 & 0.057 & 0.424 \\
\hline Places in other courses per high school graduate & 0.885 & 0.112 & 0.645 & 1.590 \\
\hline Unemployment rate & 7.870 & 1.712 & 3.875 & 11.753 \\
\hline Female & 0.597 & 0.492 & 0.000 & 1.000 \\
\hline
\end{tabular}

Note: Data collapsed into 213 state-year-sex cells, and then weighted by the number of teachers in that state. Interquartile ratio is the ratio of the wage at the 75 th percentile to the wage at the 25 th percentile.

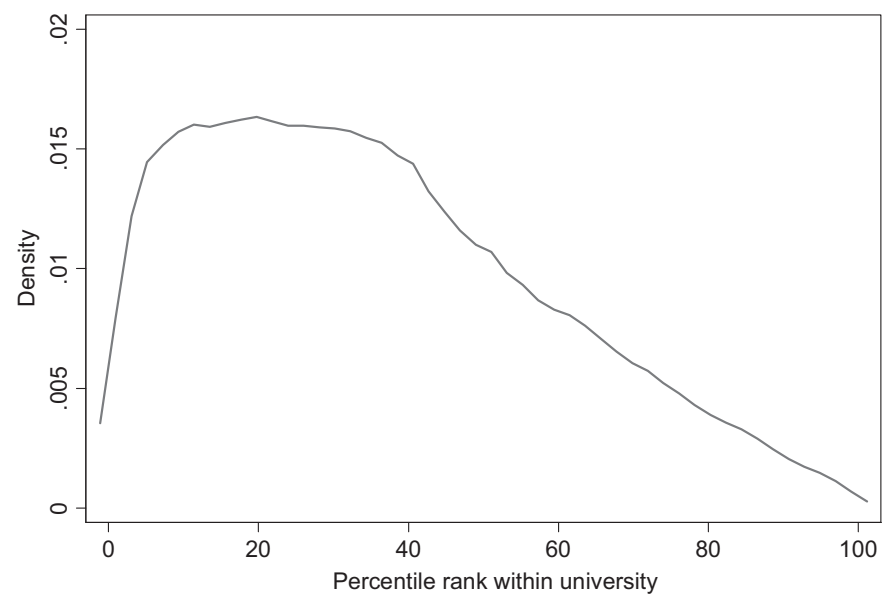

Fig. 1. Entrants into teacher education courses.

Table 2

Teacher pay and percentile rank of entrants into teacher education courses dependent variable: average percentile rank of potential teachers.

\begin{tabular}{|c|c|c|c|}
\hline & $\begin{array}{l}\text { (1) } \\
\text { All }\end{array}$ & $\begin{array}{l}\text { (2) } \\
\text { Men }\end{array}$ & $\begin{array}{l}\text { (3) } \\
\text { Women }\end{array}$ \\
\hline Log teacher salary & $\begin{array}{c}60.881^{* *} \\
{[25.672]}\end{array}$ & $\begin{array}{c}69.123^{* *} \\
{[24.273]}\end{array}$ & $\begin{array}{c}56.538 \\
{[32.035]}\end{array}$ \\
\hline Log salary in alternative occupations & $\begin{array}{c}4.924 \\
{[22.636]}\end{array}$ & $\begin{array}{c}14.525 \\
{[43.849]}\end{array}$ & $\begin{array}{c}-2.756 \\
{[20.858]}\end{array}$ \\
\hline IQR in teaching & $\begin{array}{c}-174.522 \\
{[149.467]}\end{array}$ & $\begin{array}{c}-110.252 \\
{[161.860]}\end{array}$ & $\begin{array}{c}-209.544 \\
{[172.312]}\end{array}$ \\
\hline IQR in alternative occupations & $\begin{array}{c}-454.732^{* *} \\
{[140.574]}\end{array}$ & $\begin{array}{c}-465.419^{* *} \\
{[178.288]}\end{array}$ & $\begin{array}{r}-437.187^{*} \\
{[187.294]}\end{array}$ \\
\hline Student-teacher ratio & $\begin{array}{c}1.363 \\
{[1.366]}\end{array}$ & $\begin{array}{c}0.369 \\
{[1.492]}\end{array}$ & $\begin{array}{c}2.061 \\
{[1.560]}\end{array}$ \\
\hline Teacher education places per high school graduate & $\begin{array}{l}-42.67 \\
{[70.281]}\end{array}$ & $\begin{array}{l}-24.94 \\
{[86.509]}\end{array}$ & $\begin{array}{r}-48.818 \\
{[72.835]}\end{array}$ \\
\hline Places in other courses per high school graduate & $\begin{array}{c}20.241 \\
{[24.203]}\end{array}$ & $\begin{array}{c}18.081 \\
{[27.296]}\end{array}$ & $\begin{array}{c}21.036 \\
{[26.035]}\end{array}$ \\
\hline Unemployment rate & $\begin{array}{c}-0.985 \\
{[1.155]}\end{array}$ & $\begin{array}{c}-0.721 \\
{[1.222]}\end{array}$ & $\begin{array}{c}-1.166 \\
{[1.286]}\end{array}$ \\
\hline Female & $\begin{array}{l}3.185^{* * *} \\
{[0.249]}\end{array}$ & & \\
\hline State and year fixed effects? & Yes & Yes & Yes \\
\hline Observations & 213 & 106 & 107 \\
\hline$R$-squared & 0.65 & 0.65 & 0.64 \\
\hline
\end{tabular}

Note: Data are collapsed into state-year-sex cells and then weighted by the number of teachers in that state. Robust standard errors, clustered at the state level, in brackets.

* Statistical significance at the $10 \%$ level.

** Statistical significance at the $5 \%$ level.

**** Statistical significance at the $1 \%$ level. 
specification, the coefficient on average teacher pay is 61 , suggesting that a $1 \%$ rise in average teacher pay is associated with a 0.6 point increase in the mean percentile rank of potential teachers. The coefficient is 69 for men (statistically significant at the $5 \%$ level), and 57 for women (not statistically significant).

By contrast with teacher pay, the coefficient on average pay in alternative occupations is close to zero and insignificant. The coefficient on the interquartile ratio in teaching is also statistically insignificant. This is consistent with teacher aptitude not responding to pay dispersion in the teaching sector; but more likely, it reflects the lack of merit pay for most teachers. Leigh and Ryan (2008) show that among new teachers, there were no positive returns to aptitude in teaching through the period 1983-2003. This accords with the characterization by Woessmann (2011) of Australia as being a country that does not have broadly based teacher merit pay schemes.

The interquartile ratio in alternative occupations is negative and statistically significant in all three specifications. This suggests (as a standard Roy model would predict) that a rise in earnings inequality in the non-teaching sector is likely to lower the average aptitude of potential teachers. In contrast to Flyer and Rosen (1997), who find that women are less likely to enter unequal occupations, earnings inequality does not appear to have a differential impact on the occupational choices of women and men in this sample.

Across the other controls, the student-teacher ratio is small and statistically insignificant. The controls for the number of university places are insignificant, but take the expected sign (teacher education places is negative; places in other courses is positive). The unemployment rate is negative and close to zero. Lastly, the gender coefficient suggests that the typical woman studying teacher education is of higher academic aptitude than the typical man studying teacher education. This is consistent with a number of theories, including the possibility that the non-wage attributes of teaching are valued more highly by women; or that women suffer more gender discrimination in alternative occupations than in teaching. ${ }^{17}$

Given that the university entrance score dataset contains the full universe of teacher entrance scores, it is also possible to estimate the equation at different points in the teacher aptitude distribution. Since the data are collapsed into state-year-sex cells, these effects are not estimated using quantile regressions, but instead by calculating for each state-year-sex cell the percentile rank of the teacher at the $10^{\text {th }}$ percentile, $20^{\text {th }}$ percentile, etc. ${ }^{18}$ Whereas

\footnotetext{
${ }^{17}$ By contrast, a model with the dependent variable being four-year lagged aptitude (i.e. the aptitude of starting teachers rather than those starting teacher education) produces a smaller coefficient on teacher salary and a larger coefficient on teacher pay dispersion.

18 While a quantile regression is based on the conditional distribution, this approach is based on the unconditional distribution (Koenker and Hallock, 2001). The difference between the two will depend on the difference between the conditional and unconditional density functions. As Firpo, Fortin, and Lemieux (2009) point out, 'quantile regressions are not always well suited for answering many questions of distributional interest', since 'the coefficients of a particular quantile regression cannot be used to predict the effect of a given covariate on the corresponding
}

estimating equation (3) provides an estimate of how teacher pay affected the tertiary entrance score of the average teacher, the focus here is on how teacher pay affects the test score of the bottom decile of potential teachers, second decile of potential teachers, and so on. For example, Eq. (4) shows the estimating equation where the dependent variable is the test score of the teacher education student at the 10 th percentile.

$$
\begin{aligned}
P 10(\text { TER })_{g s t}^{T C H}= & \alpha+\beta_{1} \ln \left(\bar{W}_{s t}^{T C H}\right)+\beta_{2} \ln \left(\bar{W}_{s t}^{A L T}\right) \\
& +\beta_{3} \frac{W 75_{s t}^{T C H}}{W 25_{s t}^{T C H}}+\beta_{4} \frac{W 75_{s t}^{A L T}}{W 25_{s t}^{A L T}}+\beta_{5}{\overline{\text { ClassSize }_{s t}}}^{\text {ALT }} \\
& +\beta_{6} \text { Places }_{s t}^{T C H}+\beta_{7} \text { Places }_{s t}^{A L T}+\beta_{8} \text { Unemp }_{s t} \\
& +\beta_{9} \text { Female }_{g}+\delta_{s}+\gamma_{t}+\varepsilon_{g s t}
\end{aligned}
$$

Theoretically, the Roy model has the same prediction for the $\beta_{1}-\beta_{4}$ coefficients in Eq. (4) as for these same coefficients in Eq. (3). For example, a Roy model predicts that increasing average teacher pay should increase both the mean teacher test score, and the $10^{\text {th }}$ percentile of teacher test scores. Empirically, however, it is possible that the elasticity of teacher aptitude with respect to teacher pay will differ across the distribution. To the extent that policy is more concerned with one end of the teacher aptitude distribution than the other, understanding these elasticities is relevant to thinking about the impact of salary changes.

Table 3 shows the results of this estimation, with Panel A depicting P10, P20, P30, P40, and P50, and Panel B depicting P60, P70, P80, P90, and P95. The effect of average teacher pay is statistically significant at most percentiles, with the estimated effect being strongest at the $70^{\text {th }}$ percentile, and weakest at the top and bottom. The magnitude of the coefficient at P70 is 81 , suggesting that a $1 \%$ increase in average teacher pay would raise the percentile rank of the $70^{\text {th }}$ percentile student in teacher education by 0.8 points.

Non-teacher pay and teacher pay dispersion measures are generally insignificant. Pay dispersion in non-teaching occupations is positive and statistically significant for P10-P70 and P90, with the largest coefficient at P70. This indicates that greater earnings inequality in non-teaching occupations is likely to draw more academically able individuals out of teaching. Most of the other coefficients are statistically insignificant. ${ }^{19}$

To see the effect of teacher pay across the full distribution, I re-estimate Eq. (4) for every percentile, and plot the two most statistically significant coefficients: average teacher pay and pay variance in non-teaching occupations.

\footnotetext{
quantile of the unconditional distribution'. However, their proposal of 'unconditional quantile regressions' is equally impractical given the size of the present dataset.

19 Note that the estimates in this section of the paper test the impact of salary structure at different points on the teacher test score distribution. An alternative approach is to look at the impact of the salary structure on the share of teachers in each aptitude cell for a given university and year. Analyzing the data in this manner produces qualitatively similar results.
} 
Table 3

Teacher pay and percentile rank of entrants into teacher education courses dependent variable: percentile rank of potential teachers at various percentiles.

Panel A: P10-P50

\begin{tabular}{|c|c|c|c|c|c|}
\hline & $\begin{array}{l}(1) \\
\text { P10 }\end{array}$ & $\begin{array}{l}(2) \\
\text { P20 }\end{array}$ & $\begin{array}{l}\text { (3) } \\
\text { P30 }\end{array}$ & $\begin{array}{l}(4) \\
\text { P40 }\end{array}$ & $\begin{array}{l}(5) \\
\text { P50 }\end{array}$ \\
\hline Log teacher salary & $\begin{array}{c}42.722 \\
{[32.275]}\end{array}$ & $\begin{array}{c}62.235 \\
{[34.012]}\end{array}$ & $\begin{array}{c}59.617^{*} \\
{[28.411]}\end{array}$ & $\begin{array}{c}60.195^{*} \\
{[25.644]}\end{array}$ & $\begin{array}{c}57.435^{*} \\
{[25.516]}\end{array}$ \\
\hline Log salary in alternative occupations & $\begin{array}{c}-23.827 \\
{[15.101]}\end{array}$ & $\begin{array}{c}-47.303 \\
{[26.695]}\end{array}$ & $\begin{array}{l}-28.571 \\
{[26.430]}\end{array}$ & $\begin{array}{l}-7.268 \\
{[29.107]}\end{array}$ & $\begin{array}{c}2.189 \\
{[31.599]}\end{array}$ \\
\hline IQR in teaching & $\begin{array}{r}-126.488 \\
{[99.495]}\end{array}$ & $\begin{array}{c}-214.217 \\
{[149.955]}\end{array}$ & $\begin{array}{l}-258.02 \\
{[187.360]}\end{array}$ & $\begin{array}{c}-301.739 \\
{[193.134]}\end{array}$ & $\begin{array}{l}-266.6 \\
{[198.090]}\end{array}$ \\
\hline IQR in alternative occupations & $\begin{array}{c}-410.989^{* *} \\
{[143.492]}\end{array}$ & $\begin{array}{c}-466.821^{* * *} \\
{[122.175]}\end{array}$ & $\begin{array}{c}-462.584^{* * *} \\
{[129.079]}\end{array}$ & $\begin{array}{c}-415.701^{* *} \\
{[171.443]}\end{array}$ & $\begin{array}{c}-448.495^{* *} \\
{[165.251]}\end{array}$ \\
\hline Student-teacher ratio & $\begin{array}{c}1.751 \\
{[0.982]}\end{array}$ & $\begin{array}{c}1.952 \\
{[1.437]}\end{array}$ & $\begin{array}{c}1.754 \\
{[1.423]}\end{array}$ & $\begin{array}{c}2.51 \\
{[1.584]}\end{array}$ & $\begin{array}{c}1.616 \\
{[1.635]}\end{array}$ \\
\hline Teacher education places per high school graduate & $\begin{array}{r}-114.022 \\
{[82.134]}\end{array}$ & $\begin{array}{r}-122.039 \\
{[82.881]}\end{array}$ & $\begin{array}{r}-123.543 \\
{[84.813]}\end{array}$ & $\begin{array}{c}-83.088 \\
{[82.642]}\end{array}$ & $\begin{array}{c}-78.763 \\
{[84.345]}\end{array}$ \\
\hline Places in other courses per high school graduate & $\begin{array}{c}27.651 \\
{[27.026]}\end{array}$ & $\begin{array}{c}31.874 \\
{[30.565]}\end{array}$ & $\begin{array}{c}35.978 \\
{[30.450]}\end{array}$ & $\begin{array}{c}30.113 \\
{[29.431]}\end{array}$ & $\begin{array}{c}28.579 \\
{[29.009]}\end{array}$ \\
\hline Unemployment rate & $\begin{array}{c}-0.947 \\
{[1.345]}\end{array}$ & $\begin{array}{l}-0.34 \\
{[1.350]}\end{array}$ & $\begin{array}{c}-0.274 \\
{[1.216]}\end{array}$ & $\begin{array}{c}-0.322 \\
{[1.228]}\end{array}$ & $\begin{array}{l}-0.6 \\
{[1.308]}\end{array}$ \\
\hline Female & $\begin{array}{c}1.309^{* *} \\
{[0.385]}\end{array}$ & $\begin{array}{l}2.106^{* * *} \\
{[0.389]}\end{array}$ & $\begin{array}{c}2.583^{* * *} \\
{[0.296]}\end{array}$ & $\begin{array}{l}2.763^{* * *} \\
{[0.385]}\end{array}$ & $\begin{array}{l}3.484^{* * *} \\
{[0.265]}\end{array}$ \\
\hline State and year fixed effects? & Yes & Yes & Yes & Yes & Yes \\
\hline$R$-squared & 0.53 & 0.55 & 0.59 & 0.62 & 0.63 \\
\hline \multicolumn{6}{|l|}{ Panel B: P60-P95 } \\
\hline & P60 & P70 & P80 & P90 & P95 \\
\hline Log teacher salary & $\begin{array}{c}68.526^{* *} \\
{[25.929]}\end{array}$ & $\begin{array}{c}81.017^{* *} \\
{[28.540]}\end{array}$ & $\begin{array}{c}76.829^{*} \\
{[33.431]}\end{array}$ & $\begin{array}{c}68.774^{* *} \\
{[27.876]}\end{array}$ & $\begin{array}{c}37.089 \\
{[21.724]}\end{array}$ \\
\hline Log salary in alternative occupations & $\begin{array}{c}20.779 \\
{[29.272]}\end{array}$ & $\begin{array}{c}26.966 \\
{[31.982]}\end{array}$ & $\begin{array}{c}32.063 \\
{[25.410]}\end{array}$ & $\begin{array}{c}65.194^{*} \\
{[29.969]}\end{array}$ & $\begin{array}{c}30.316 \\
{[38.888]}\end{array}$ \\
\hline IQR in teaching & $\begin{array}{c}-243.919 \\
{[189.008]}\end{array}$ & $\begin{array}{c}-216.131 \\
{[161.047]}\end{array}$ & $\begin{array}{r}-196.427 \\
{[157.787]}\end{array}$ & $\begin{array}{c}-41.467 \\
{[165.580]}\end{array}$ & $\begin{array}{c}144.756 \\
{[242.276]}\end{array}$ \\
\hline IQR in alternative occupations & $\begin{array}{c}-549.125^{* *} \\
{[158.746]}\end{array}$ & $\begin{array}{c}-610.326^{* *} \\
{[196.822]}\end{array}$ & $\begin{array}{c}-577.407 \\
{[319.763]}\end{array}$ & $\begin{array}{r}-538.937^{*} \\
{[278.585]}\end{array}$ & $\begin{array}{c}-238.683 \\
{[210.096]}\end{array}$ \\
\hline Student-teacher ratio & $\begin{array}{c}1.333 \\
{[1.675]}\end{array}$ & $\begin{array}{c}1.127 \\
{[1.879]}\end{array}$ & $\begin{array}{c}0.964 \\
{[2.203]}\end{array}$ & $\begin{array}{c}1.188 \\
{[2.011]}\end{array}$ & $\begin{array}{c}0.73 \\
{[1.404]}\end{array}$ \\
\hline Teacher education places per high school graduate & $\begin{array}{c}-66.874 \\
{[80.577]}\end{array}$ & $\begin{array}{c}-14.345 \\
{[81.919]}\end{array}$ & $\begin{array}{c}23.196 \\
{[105.025]}\end{array}$ & $\begin{array}{l}118.805 \\
{[95.297]}\end{array}$ & $\begin{array}{l}148.187^{*} \\
{[75.929]}\end{array}$ \\
\hline Places in other courses per high school graduate & $\begin{array}{c}25.459 \\
{[27.022]}\end{array}$ & $\begin{array}{c}14.558 \\
{[25.843]}\end{array}$ & $\begin{array}{c}-0.503 \\
{[25.027]}\end{array}$ & $\begin{array}{l}-8.53 \\
{[20.788]}\end{array}$ & $\begin{array}{c}4.518 \\
{[14.849]}\end{array}$ \\
\hline Unemployment rate & $\begin{array}{c}-0.838 \\
{[1.392]}\end{array}$ & $\begin{array}{c}-0.817 \\
{[1.527]}\end{array}$ & $\begin{array}{l}-2.006 \\
{[1.475]}\end{array}$ & $\begin{array}{c}-2.053 \\
{[1.638]}\end{array}$ & $\begin{array}{c}-2.394 \\
{[1.406]}\end{array}$ \\
\hline Female & $\begin{array}{l}3.683^{* * *} \\
{[0.285]}\end{array}$ & $\begin{array}{c}4.835^{* * *} \\
{[0.397]}\end{array}$ & $\begin{array}{l}5.175^{* * *} \\
{[0.424]}\end{array}$ & $\begin{array}{c}4.424^{* * *} \\
{[0.725]}\end{array}$ & $\begin{array}{c}4.262^{* * *} \\
{[0.908]}\end{array}$ \\
\hline State and year fixed effects? & Yes & Yes & Yes & Yes & Yes \\
\hline$R$-squared & 0.65 & 0.65 & 0.61 & 0.54 & 0.56 \\
\hline
\end{tabular}

Note: Data are collapsed into state-year-sex cells and then weighted by the number of teachers in that state. Robust standard errors, clustered at the state level, in brackets.

* Statistical significance at the $10 \%$ level.

** Statistical significance at the 5\% level.

${ }^{* * *}$ Statistical significance at the $1 \%$ level.

Fig. 2 shows the relationship between average teacher pay and the aptitude of potential teachers, while Fig. 3 shows the relationship between earnings inequality in the nonteaching sector and the aptitude of potential teachers. In both charts, dashed lines denote $95 \%$ confidence intervals. While the effect of average teacher pay is strongest at the median, the effect of earnings inequality in the non-teaching sector is stronger towards the top of the distribution.

As noted above, a Roy model does not predict that the effect of average pay and pay dispersion will be smaller at the tails of the distribution than at the middle of the distribution. So what factors might explain the attenuation of the effects towards the tails in Figs. 2 and 3? At the bottom of the distribution, one possibility is that those who are narrowly scraping into teacher education courses are less likely to successfully complete the course, and are therefore less responsive to the salary in teaching and nonteaching occupations. Another possibility is that those at the bottom of the teaching distribution have less access to information about the labor market, which would also predict a lower elasticity. At the top of the distribution, one possible reason why the estimated elasticity might be lower is if the top tail of teachers are high-achievers who 


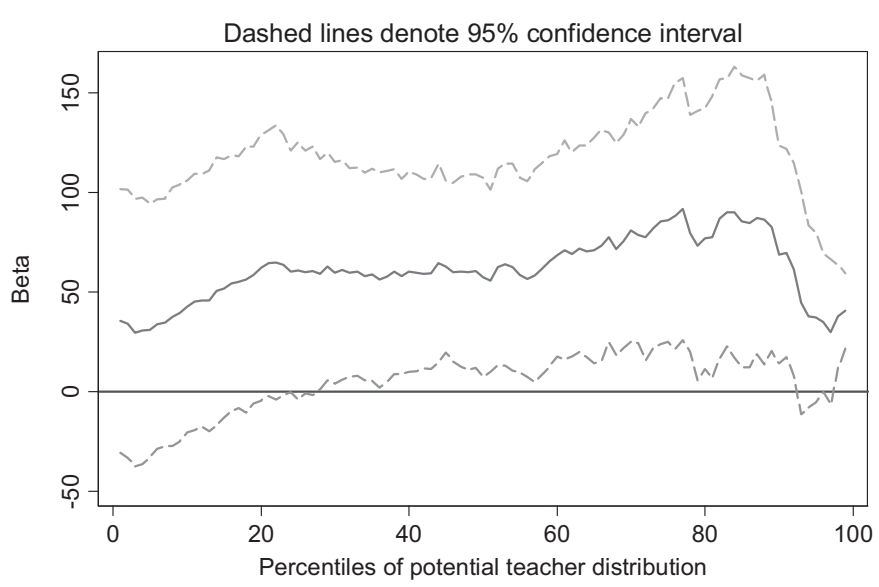

Fig. 2. Marginal effect of Log average teacher pay by percentile. Note: Graph shows the point estimates and associated standard errors on the average teacher pay measure. Calculated by re-estimating Eq. (4), with the dependent variable ranging from P1 to P99.

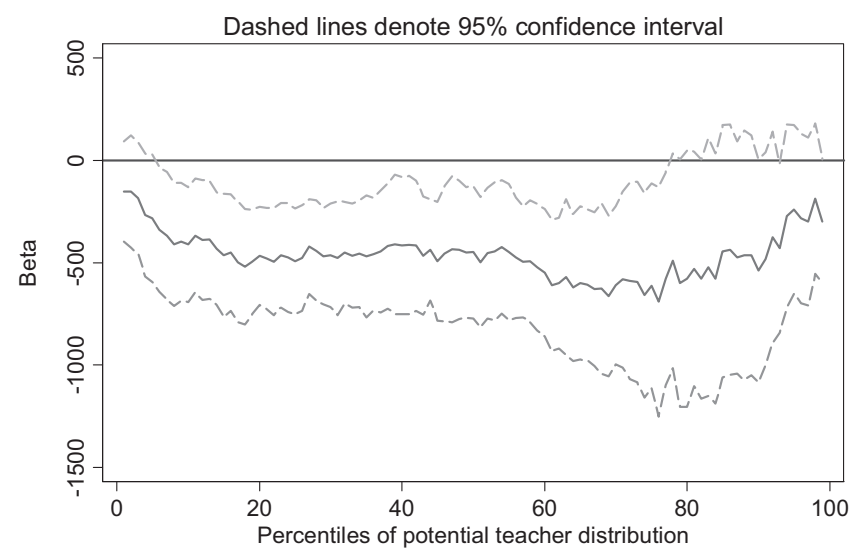

Fig. 3. Marginal effect of pay variance among non-teachers by percentile. Note: Graph shows the point estimates and associated standard errors for non-teacher IQR. Calculated by re-estimating Eq. (4), with the dependent variable ranging from P1 to P99.

are choosing teaching for altruistic rather than financial reasons. ${ }^{20}$

What do these results suggest for the way in which a given change in average starting teacher pay might affect the distribution of potential teachers? To see this, Fig. 4 simulates a $5 \%$ pay rise for all new teachers. To put this into an international context, the average starting salary for a lower secondary education teacher in the OECD in 2006 was US $\$ 30,047$ (OECD, 2008, Table D3.1), so a 5\% increase would involve raising starting salaries to US\$31,549. Note that what is being simulated is a $5 \%$ rise in the pay of teachers holding constant other graduate salaries, so in reality such a reform would probably require a nominal increase in teacher pay in a single year that was closer to $10 \%$. The

\footnotetext{
20 Since the dependent variable is the teacher education students' relative position in the distribution, it is theoretically possible that another explanation for the low elasticity at the top of the distribution is an upperbound effect (if the best teacher education students are already the best students in the university, higher teacher pay cannot increase their relative position in the distribution). In practice, the best teacher education students are also the best students in the university only 5 percent of the time, suggesting that the upper bound probably does not explain the lower elasticity at the top.
}

estimates in Fig. 4 are based on the coefficient estimates depicted in Fig. 2, which allow the impact of average pay to have a different impact at each point in the aptitude distribution. The dashed line shows the kernel density estimate of the new distribution, with fewer potential teachers below the median, and more potential teachers above the median.

\section{Instrumenting teacher pay with uniform salary schedules}

As a robustness check, I instrument the average pay of a starting teacher using each state's uniform teacher salary schedules for public school teachers. This helps to deal with potential measurement error when using the Graduate Destination Survey. Further, the instrumental variables approach will be useful if private schools (which have more flexibility in setting pay rates) set salaries with an eye to the aptitude of those entering teacher education courses. However, since the typical teacher education student will not become a teacher for another four years, endogeneity seems unlikely to be a major problem. 


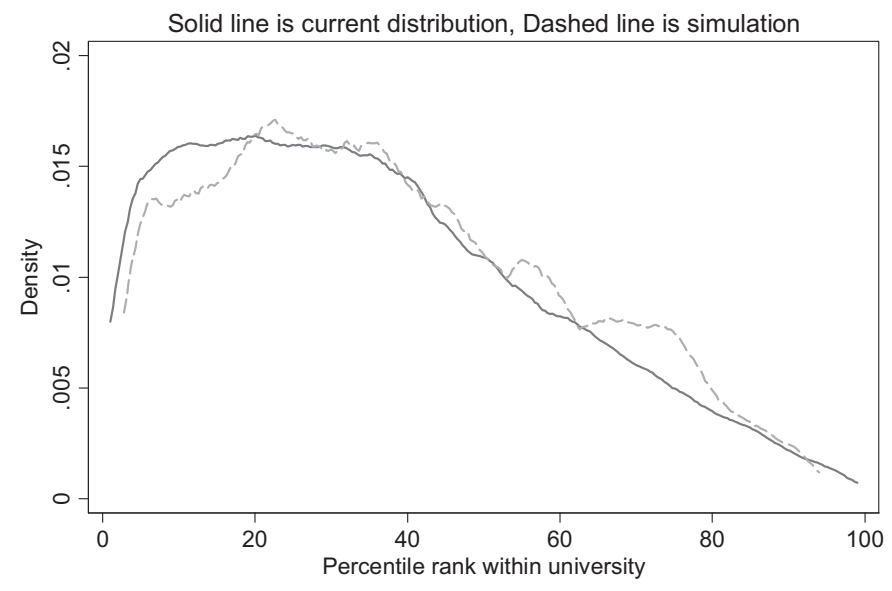

Fig. 4. Simulated $5 \%$ pay rise for all teachers.

Uniform salary schedules cover all public school teachers in a given state. (Around three-quarters of all teachers work in public schools.) Changes in teacher salary schedules are the result of collective bargaining agreements between the state's teacher union and the state government. The size of the salary increase will therefore be driven by the relative power of the teacher unions at a given point

Table 4

Instrumenting with uniform salary schedules dependent variable: average percentile rank of potential teachers.

\begin{tabular}{lcc}
\hline & $(1)$ & $(2)$ \\
& IV & Reduced form \\
\hline Log teacher salary & $83.432^{*}$ & 31.575 \\
& {$[39.920]$} & {$[19.728]$} \\
Log salary in alternative & 5.885 & 18.143 \\
occupations & {$[24.772]$} & {$[26.630]$} \\
& -204.809 & -51.136 \\
IQR in teaching & {$[131.783]$} & {$[129.444]$} \\
& $-439.355^{* *}$ & $-500.207^{* *}$ \\
IQR in alternative occupations & {$[163.509]$} & {$[154.020]$} \\
& 1.439 & 1.341 \\
Student-teacher ratio & {$[1.416]$} & {$[1.253]$} \\
& -21.959 & -52.454 \\
Teacher education places per & & \\
high school graduate & {$[102.385]$} & {$[89.824]$} \\
& 17.923 & 20.701 \\
Places in other courses per & & \\
high school graduate & {$[26.396]$} & {$[29.665]$} \\
& -0.922 & -1.529 \\
Unemployment rate & {$[1.182]$} & {$[1.201]$} \\
& $3.186^{* * *}$ & $3.183^{* * *}$ \\
Female & {$[0.251]$} & {$[0.250]$} \\
& Yes & Yes \\
State and year fixed effects? & 0.64 & 0.62 \\
$R$-squared & 34.67 & \\
$F$-test on excluded instrument & {$[P=0.0001]$} & \\
& & \\
\hline
\end{tabular}

Note: Data are collapsed into state-year-sex cells and then weighted by the number of teachers in that state. Robust standard errors, clustered at the state level, in brackets. In column 1, teacher pay is instrumented with the log of the starting salary for a beginning teacher in a public school in a given state and year. In column 2, teacher pay is the log of the starting salary for a beginning teacher in a public school in a given state and year

* Statistical significance at the $10 \%$ level.

** Statistical significance at the $5 \%$ level.

${ }^{* * *}$ Statistical significance at the $1 \%$ level. in time, the political party in office at the state level, and the timing of other events such as state elections. More information on the teacher pay schedules is provided in the Data Appendix.

The first column of Table 4 instruments teacher pay with the starting pay from uniform salary schedules. The second column presents reduced form results, with uniform salary schedules used in place of estimated teacher pay. In both specifications, there remains a positive relationship between teacher salary and the aptitude of new teachers. In the IV specification, the coefficient on average teacher pay is 83 (significant only at the 10\% level). In the reduced-form specification, the coefficient on average teacher pay is 32 (not statistically significant). Together, these results suggest that a $1 \%$ rise in average teacher pay leads to a $0.3-0.8$ point increase in the mean percentile rank of potential teachers, which is broadly consistent with the result in Table 2 .

\section{Conclusion}

Combining two rich datasets - on the test scores for students entering universities, and on graduate salaries - I estimate the impact of salary variation across states on the aptitude of potential teachers. The relationship between average pay and teacher aptitude is positive and significant: a $1 \%$ rise in teacher pay (relative to other occupations requiring a college degree) is associated with approximately a 0.6 point rise in the average percentile rank of potential teachers. This result is robust to instrumenting for average teacher pay using uniform salary schedules for public school teachers. The aptitude of potential teachers is also negatively associated with pay dispersion in non-teaching occupations, suggesting that earnings inequality in the non-teaching sector may hurt the teaching profession.

The Australian educational system has certain features that facilitate the empirical analysis presented in this paper. Because teacher salaries in public schools are negotiated on a statewide basis, and university applicants choose their field of study at the time of entering university, it is possible to avoid the endogeneity problem in 
estimating the impact of teacher pay on the aptitude of potential teachers. And because selection into university is based solely on exam scores, an increase in applicants (holding the number of places constant) automatically leads to an improvement in the average exam score of teacher education students. ${ }^{21}$ However, in other respects such as the average level of teacher pay, the structure of the teacher labor market, and the level of union membership in the teaching profession - Australia is quite typical of other OECD countries (McKenzie, Santiago, \& Organisation for Economic Cooperation and Development (OECD), 2005; OECD, 2008). This suggests that the findings here are potentially applicable to other developed countries as well.

Finally, it should be emphasized that this paper focuses only on the effect of changes in teacher pay on the pool of potential teachers (i.e. those who enroll in teacher education courses). While this makes it possible to separately identify supply-side effects, this method has the disadvantage that not all potential teachers will enter the teaching profession. Inevitably, some of those who enter teacher education courses will switch into other courses, drop out of university altogether, or graduate and enter a nonteaching occupation. Most likely, those who switch into other courses will have higher test scores, in which case the estimates above probably overstate the impact of pay on teacher aptitude. On the flipside, those who drop out of teacher education courses and those who enter alternative occupations may be those with lower test scores, in which case the exercise above may be an underestimate of the true impact of pay on teacher aptitude. Nonetheless, the fact that those entering teacher education courses do appear to be responding to the incentives offered to current teachers indicates that changing the teacher salary structure is a promising way of improving the quality of the future teaching workforce.

\section{Appendix A. Data Appendix}

\section{A.1. University entrance data}

Entry into most university courses is based solely upon statewide standardized tests. In November of each year, prospective students rank university courses and universities. When results from the standardized test are released in January, students typically have a short period in which to change their course and university preferences. The number of places in each course and university is determined by the federal and state governments.

Data are drawn from the Student Enrolment file maintained by the Department of Employment, Science and Training (DEST), which contains the course choice, institution, tertiary entrance rank (TER), and basic demographic information on every individual admitted into a university between 1989 and 2003. The data used in this paper cover all students entering undergraduate and

\footnotetext{
${ }^{21}$ In countries where university entrance is based on factors other than exam scores, it is nonetheless likely to be the case that an increase in the number of applicants (holding the number of places constant) will raise the academic aptitude of the entering student cohort.
}

diploma courses, but not those entering postgraduate courses, nor overseas students. For the years 1999-2003, the tertiary entrance rank is expressed in the dataset as a comparable Universities Admissions Index, but for prior years the scaling varies across states and years. The test scores in each state and year were therefore rescaled into within-state percentile ranks.

If a university reported the same score for all students, all scores for that university are dropped. Additionally, if a university reported on a different scale from most of the other universities in its state, all scores from that university are dropped. This has an effect on the sample size in two states with only one university - the Northern Territory and Tasmania. Because of missing TER values, the sex-state-year cells for the Northern Territory are missing in 1990-1994 for males and females, and in 1998 for males. Likewise, the sex-state-year cells for Tasmania are missing in 1989-1994 for males and females.

After the within-university test scores of those entering teacher education courses had been calculated, those in other courses were dropped from the sample. Teacher education courses were defined as courses with Field of Study codes 50101-50499 in 1989-2000, and those with Field of Education codes 70100-79999 in 2001-2003.

The number of applicants into teacher education and alternative courses are both divided by the number of students enrolled in year 12 in that state in the previous year (taken from the Australian Bureau of Statistics publication Schools: Australia, various years).

\section{A.2. Salary data}

Annual salaries are derived from the 1988-2002 Graduate Destination Survey (GDS), a mailout survey administered to all recent university graduates. The response rate for the survey is around $60-70$ percent. Universities administer the survey, and have an incentive to ensure a high response rate. If an institution does not achieve a 50 percent response rate, its data are not included in the public tabulations of the survey results.

I restrict the sample to those who have just graduated with a bachelor's degree or a diploma, and are working full-time. Earnings are dropped if they are more than three interquartile ranges below the $25^{\text {th }}$ percentile of the national earnings distribution, or more than three interquartile ranges above the $75^{\text {th }}$ percentile. In other words, where P25 and P75 are the $25^{\text {th }}$ and $75^{\text {th }}$ percentiles respectively, I drop observations that are below $\{\mathrm{P} 25-3(\mathrm{P} 75-\mathrm{P} 25)\}$ or above $\{\mathrm{P} 75+3(\mathrm{P} 75-\mathrm{P} 25)\}$.

The number of full-time primary and secondary school teachers in the surveys averages 5215 per year, while the number of full-time graduates working in other occupations averages 30,420 per year. When the data are collapsed into state-year cells, the number of teachers averages 658 (the range is from 48 to 2291), while the number of graduates in other occupations averages 3824 (ranging from 183 to 12,038). In 1988, the Australian Capital Territory and the Northern Territory were not separately identified in the GDS, so the two territories are not included in the analysis for the first year. 
The GDSs are conducted in April of each year, using a sample of individuals who completed university the previous year. Respondents are asked for their annual salary. This salary data is then matched to the tertiary entrance ranking of those entering university the following year.

Over the period 1989-2003, the GDS is the only publicly accessible dataset that contains annual earnings data on a state basis for fine occupational categories. Other largescale surveys (such as the five-yearly Census or the Survey of Income and Housing Costs) are not conducted annually, and in most years the microdata only categorize occupations at the one-digit level. The Employee Earnings and Hours survey is conducted biennially, but the published tables do not separate occupational earnings by state, and the Australian Bureau of Statistics does not permit outside researchers to access the microdata.

In Section 5 of the paper, I experiment with instrumenting for the pay ratio in teaching with the official salary to be paid to a beginning teacher in a government school. To construct these series, I wrote to all state and territory education ministers, requesting historical teacher salary schedules. Ultimately, I was able to obtain data for all states and years except Queensland for 1988-1993, Western Australia for 1988-1995, and New South Wales for 1988. (For these states and years, I interpolate the starting pay, assuming the same annual rate of change as in the other states in the same years.) I use as the beginning teacher salary the salary paid to a teacher at the bottom of the salary scale. In some instances, teachers with four-year qualifications are not paid at the bottom of the salary scale. However, since all specifications include state fixed effects, the results are identified from the timing of within-state salary changes, rather than cross-state differences in salary levels. Since salary increments almost always raise salaries by the same percentage for teachers at all points in the scale, it will not matter whether the typical teacher actually commences at the fourth rung of the salary schedule or the first rung of the salary schedule (so long as the entry point does not change over time). As with the teacher salary data gathered from the Graduate Destination Survey, pay scales are matched to the tertiary entrance ranking of those entering university the following year.

\section{A.3. Unemployment rates}

Unemployment rates are drawn from Australian Bureau of Statistics, Labour Force, Australia, Detailed, Cat No 6291.0.55.001. Table 02: Labour force status by State.

\section{A.4. Student-teacher ratio}

Student-teacher ratios are drawn from Australian Bureau of Statistics, Schools: Australia, Cat No 4221.0. In 1988 and 1989, ratios are calculated by combining data in Tables 7 and 18. In subsequent years, the figures are listed in Table 18 (1990-1992), Table 20 (1993-1994), Table 21 (1995-1996), Table 55 (1997-1999) and Table 54 (2000-2003). The figures are student-teaching staff ratios in 1990-2001, and full-time equivalent studentteaching staff ratios in 1988-1989 and 2002-2003. They are a weighted average across primary and secondary schools, and across the government and non-government sectors.

\section{A.5. Sample weights}

All estimates are weighted by the full-time equivalent size and gender split of the teaching workforce in that state in 1988 (taken from the Australian Bureau of Statistics publication Schools: Australia 1988, Table 17).

\section{References}

Bacolod, Marigee P. (2007). Do alternative opportunities matter? The role of female labor markets in the decline of teacher quality, 1960-1990. Review of Economics and Statistics, 89(4), 737-751.

Ballou, Dale, \& Podgursky, Michael. (1995). Recruiting smarter teachers. Journal of Human Resources, 30(2), 326-338.

Ballou, Dale, \& Podgursky, Michael. (1997). Teacher pay and teacher quality. Kalamazoo, MI: Upjohn.

Bertrand, M., Duflo, E., \& Mullainathan, S. (2004). How much should we trust differences-in-differences estimates? Quarterly Journal of Economics, 119(1), 249-275.

Betts, Julian. (1995). Does school quality matter? Evidence from the national longitudinal survey of youth. Review of Economics and Statistics, 77, 231-247.

Boarini, Romina, \& Lüdemann, Elke. (2009). The role of teacher compensation and selected accountability policies for learning outcomes: an empirical analysis for OECD countries. OECD Journal: Economic Studies Volume, 2009, 211-230.

Card, David, \& Krueger, Alan B. (1992). Does school quality matter? Returns to education and the characteristics of public schools in the United States. Journal of Political Economy, 100(1), 1-40.

Chung, Tsung-Ping, Dolton, Peter, \& Tremayne, Andrew. (2004). The determinants of teacher supply: Time series evidence for the UK, 1962-2001, Mimeo. Centre for Economic Performance, London School of Economics.

Clotfelter, Charles T., Ladd, Helen F., \& Vigdor, Jacob L. (2006). Teacher-student matching and the assessment of teacher effectiveness. Journal of Human Resources, 41(4), 778-820.

Clotfelter, Charles T., Glennie, Elizabeth, Ladd, Helen F., \& Vigdor, Jacob L. (2008). Would higher salaries keep teachers in high-poverty schools? Evidence from a policy intervention in north Carolina. Journal of Public Economics, 92, 1352-1370.

Corcoran, Sean P., Evans, William N., \& Schwab, Robert M. (2004). Changing labor market opportunities for women and the quality of teachers, 1957-2000. American Economic Review, 94(2)

Department Employment, Science and Training (DEST). (2003). Selected higher education statistics. Canberra: DEST.

Department of Education, Science and Training (DEST). (2007). Selected higher education statistics. Students 2006 (Full Year). Canberra: DEST.

Dolton, Peter, \& Marcenaro-Gutierrez, Oscar D. (2011). If you pay peanuts do you get monkeys? A cross-country analysis of teacher pay and pupil performance. Economic Policy, 26(65), 5-55.

Dolton, P., \& van der Klaauw, W. (1999). The turnover of teachers: a competing risks explanation. Review of Economics and Statistics, 81(3), 543-550.

Ehrenberg, Ronald G., \& Brewer, Dominic J. (1994). Do school and teacher characteristics matter? Evidence from high school and beyond. Economics of Education Review, 13(1), 1-17.

Ferguson, Ronald F. (1991). Paying for public education: new evidence on how and why money matters. Harvard Journal on Legislation, 28(2), 465-498.

Ferguson, Ronald F., \& Ladd, Helen F. (1996). How and why money matters: an analysis of Alabama schools. In F. Helen, \& Ladd (Eds.), Holding schools accountable. Performance-based reform in education. Washington, DC: Brookings Institution.

Figlio, David N. (1997). Teacher salaries and teacher quality. Economics Letters, 55, 267-271.

Figlio, David N., \& Rueben, Kim S. (2001). Tax limits and the qualifications of new teachers. Journal of Public Economics, 80(1), 49-71.

Firpo, Sergio, Fortin, Nicole M., \& Lemieux, Thomas. (2009). Unconditional quantile regressions. Econometrica, 77(3), 953-973.

Flyer, Fredrick, \& Rosen, Sherwin. (1997). The new economics of teachers and education. Journal of Labor Economics, 15(1, Part 2), S104-S139. 
Freeman, Richard B. (1976). A cobweb model of the supply and starting salary of new engineers. Industrial and Labor Relations Review, 29(2), 236-248.

Frijters, Paul, Shields, Michael A., Wheatley-Price, Stephen, 2004. To teach or not to teach? Panel Data Evidence on the Quitting Decision. IZA Discussion Paper 1164. Bonn.

Goldhaber, Dan. (2007). Everyone's doing it, but what does teacher testing tell us about teacher effectiveness? Journal of Human Resources, 42(4), 765-794.

Grogger, Jeff. (1996). School expenditures and post-schooling earnings: evidence from high school and beyond. Review of Economics and Statistics, 78, 628-637.

Hanushek, Eric A. (1997). Assessing the effects of school resources on student performance: an update. Educational Evaluation and Policy Analysis, 19(2), 141-164.

Hanushek, E.A., Kain, J.F., Rivkin, S.G., 1999. Do higher salaries buy better teachers? NBER Working paper 7082. Cambridge, MA.

Hanushek, E. A. (2006). School resources. In Eric A. Hanushek, \& Finis Welch (Eds.), Handbook of the economics of education (pp. 865-908). Amsterdam: Elsevier.

Healy, G., 2008. Student places lost to the boom, The Australian, 9 April, Higher Education Supplement.

Hoxby, Caroline M., \& Leigh, Andrew. (2004). Pulled away or pushed out? Explaining the decline of teacher quality in the United States. American Economic Review, 94(2), 236-240.

Koenker, Roger, \& Hallock, Kevin F. (2001). Quantile regression. Journal of Economic Perspectives, 15(4), 143-156.

Leigh, Andrew, Mead, Sara, 2005. Lifting Teacher Performance, Policy Report, Progressive Policy Institute, Washington, DC.

Leigh, Andrew, \& Ryan, Chris. (2006). How and why has teacher quality changed in Australia? Australian National University CEPR Discussion Paper 534. ANU: Canberra.

Leigh, Andrew, \& Ryan, Chris. (2008). How and why has teacher quality changed in Australia? Australian Economic Review, 41(2), 141-159.

Loeb, Susanna, \& Page, Marianne. (2000). Examining the link between teacher wages and student outcomes: the importance of alternative labor market opportunities and non-pecuniary variation. Review of Economics and Statistics, 82(3), 393-408.

Marks, G., Fleming, N., 1998. Youth earnings in Australia 1980-1994: a comparison of three youth cohorts, Longitudinal Surveys of Australian Youth Research Report No. 8, Melbourne: ACER.

McKenzie, P., Santiago, P., \& Organisation for Economic Cooperation and Development (OECD). (2005). Teachers matter: Attracting, developing and retaining effective teachers. Paris: OECD Publishing.

Murnane, Richard J., Willett, John B., \& Levy, Frank. (1995). The growing importance of cognitive skills in wage determination. Review of Economics and Statistics, 77, 251-266.

Organisation for Economic Cooperation and Development (OECD). (2008). Education at a glance 2008: OECD indicators. Paris: OECD Publishing.

Rivkin, Steven G., Hanushek, Eric A., \& Kain, John F. (2005). Teachers, schools, and academic achievement. Econometrica, 73(2), 417-458.

Rockoff, Jonah E. (2004). The impact of individual teachers on student achievement: evidence from panel data. American Economic Review, 94(2), 247-252.

Rockoff, Jonah E., Jacob, Brian A., Kane, Thomas J., Staiger, Douglas O., 2008. Can You Recognize an Effective Teacher When You Recruit One? NBER Working Paper No. 14485. NBER, Cambridge, MA.

Rosen, Sherwin. (1992). The market for lawyers. Journal of Law and Economics, 35(2), 215-246.

Roy, A. D. (1951). Some thoughts on the distribution of earnings. Oxford Economic Papers, 3, 135-146.

Ryoo, Jaewoo, \& Rosen, Sherwin. (2004). The engineering labor market. Journal of Political Economy, 112(s1), S110-S140.

Webster, Elizabeth, Wooden, Mark, Marks, Gary, 2004. Reforming the Labour Market for Australian Teachers, Melbourne Institute Working Paper No. 28/04.

Woessmann, Ludger. (2011). Cross-country evidence on teacher performance pay. Economics of Education Review, 30(3), 404-418.

Zabalza, A. (1979). The determinants of teacher supply. Review of Economic Studies, 46(1), 131-147. 